\title{
Revision Through Twitter: Do Tweets Affect Students' Performance?
}

\author{
$\underline{\text { http://dx.doi.org/10.3991/ijet.v11i04.5124 }}$ \\ J. Juhary \\ National Defence University of Malaysia, Kuala Lumpur, Malaysia
}

\begin{abstract}
Twitter is one of the free micro bloggings available today. Created in 2006, Twitter has about 500 million registered users worldwide. Many scholars have been debating over the use of Twitter in teaching and learning. This brief research paper aims to look at Twitter as a source of revision for a course offered at the Defence University in Kuala Lumpur. The assumption is that the students are able to score a higher grade when Twitter is used as a revision tool. 32 students participated in this study and tweets were used to support students during their revision period before the second test. Data were analysed based on the results of Test 1 (without Twitter as a revision tool) and Test 2, where comparisons were made to see whether there is a change in the students' results. Further, the tweets sent to/shared with students and the retweets shared by students were also examined. A survey was also conducted to explore the respondents' thoughts on using Twitter as a revision tool. Preliminary findings suggest that the students had greatly benefitted when Twitter is used as a revision tool. This is because the results of Test 2 show that all students scored higher. The results of the survey also indicate that students were positive about using Twitter as a revision tool. Although it cannot be conclusively determined whether Twitter is the only factor that contributes to the increase of students' results in Test 2, this paper will highlight how Twitter can be used as an effective revision tool.
\end{abstract}

Index Terms-Defence University, micro blogging, tweets, Twitter

\section{INTRODUCTION}

In 2006, Jack Dorsey, Evan Williams, Biz Stone and Noah Glass created Twitter. Their intention was initially to allow people to post short status/comments [1] and ever since, Twitter has evolved in terms of its functions that include sharing of pictures, videos and links. Twitter is one of the free micro bloggings available today. Students nowadays respond very well to social media including Twitter because these students are what scholars called the Digital Natives [2]. Borne after 1980s, these students are well versed with the use and functions of digital technologies. It is argued that since students are now more accepting of new technologies, the learning and teaching processes must also incorporate the use of digital technologies [3]. Thus, students have more and better options as their learning tools.

This paper aims to look at Twitter as a source of revision for a course offered at the Defence University in Kuala Lumpur. The assumption is that the students are able to score a higher grade when Twitter is used as a revision tool. This assumption is to be tested at the Defence University in Kuala Lumpur, Malaysia. The Nation- al Defence University of Malaysia (NDUM) is Malaysia's youngest public university, and since its inception in 2007 , about 1,800 students have graduated from the university. As a residential campus, with a total student population of about 2,200, the students are governed in a manner that instils order and discipline. Students are categorised into two including military cadets and reserved officers, and both categories of students are not given permission to leave campus on weekdays and selected weekends. Therefore, students have to rely on technology, for instance, to get the required experience (by this, technology allows the students to read about and watch the current issues/news; to perform online transactions; and to socialise).

This paper has two main objectives as detailed below.

1. To determine whether Twitter can be used effectively as a revision tool

2. To investigate how Twitter assists students to learn better

\section{A. The Significance of the Study}

Some academic courses require students to understand critical concepts before they can understand and argue about the concepts. Most students fail at understanding critical concepts simply because they are not keen to read their notes (could this be contributed to their status as Digital Natives? Unfortunately, this paper is not able to verify this). Various strategies have been adopted including short notes or point notes that students prepare before the tests. What happens after the test is ironic; they abandon the notes. Therefore, it can be argued that perhaps if technology was used as a revision tool, the notes would be available forever for students to refer to. Since students can refer to the notes anytime anywhere, there is no excuse for the students not to perform better academically and most importantly for them to be meaningfully engaged in their learning. This paper uses Twitter as a revision tool because of its omnipresence, functions and its limited word counts for each tweet, which allows for precise and concise notes, critical during revision sessions. It then seeks to test whether Twitter has helped students to revise effectively or not.

\section{B. Selected Literature}

Much of the literature on Twitter falls under the category of Web 2.0 tools. In addition, Twitter has been considered positively in teaching and learning. It becomes popular because users can "build up an instant, personalised Twitter feed" [4] that meets the interests of the users. Students are able to search and to select the best materials or information, and then share them. Further, Ferenstein 
[5] argued that Twitter helps to boost students' engagement in classroom learning because they can tweet and ask questions, and then receive feedback in real time. He then suggested that the tweeting activities could continue even after class, and as such this builds a community outside classroom learning. More importantly the community built lasts for a long time even after the completion of the course that uses Twitter [6]. Marr and DeWaele [7] suggested that Twitter allows students to become more creative in their learning and facilitates class discussions on the weekly lessons, where students interact with contents as well as their classmates [8].

Embi [9] suggested 10 advantages of Twitter in teaching and learning including Twit Board that notifies students of changes to course content or schedules; Micro Write which allows students to perform progressive collaborative writing on Twitter; and Time Tweet which allows students to choose a famous person from the past and create an account for them (then students can mimic the way the person writes or his/her thoughts that can be useful for further discussion). Moreover, other researchers have suggested that Twitter is very useful for informal learning, to discover relevant resources and seek assistance from other people [10], [11]. McArthur and Bostedo-Conway [12] found through their quantitative study that Twitter can serve as a valuable tool to supplement the chalk and talk approach to teaching and learning. It is further argued that students could foster critical thinking skills when they use Twitter appropriately.

Twitter can be used in various ways during classroom sessions, especially as an instructional tool [13] and it helps students learn by note taking and recall [14]. As demonstrated in Figure 1 below, the strategy to use Twitter depends on the learning outcomes that want to be accomplished. As suggested in the figure too, students become more active when they become more articulate during the lessons. Active students may develop critical thinking because they are involved in classroom discussions meaningfully.

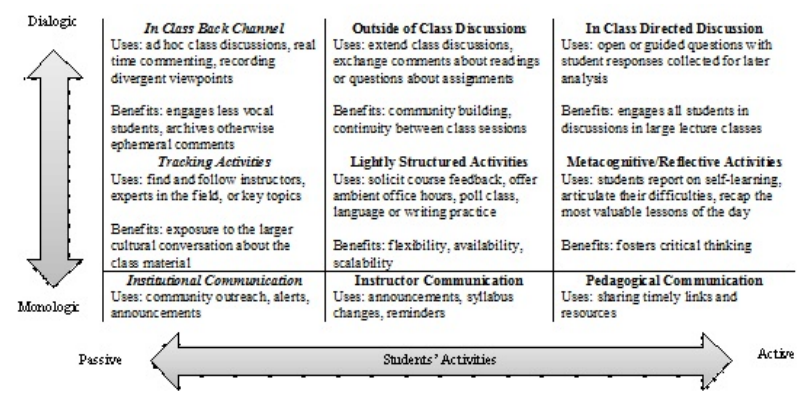

Figure 1. Twitter Adoption Matrix (original concept by Rick Reo; revised by Mark Sample [15])

Apart from using Twitter for classroom teaching and learning, Twitter is argued to have added an extra value for research projects [16]. This is because students are able to share and project themselves in the research community using the hashtag sign (\#). Users of Twitter would be able to search for students' works by using these dedicated hashtags. According to Mollet, Moran and Dunleavy [17], Twitter provides more opportunities for crowd sourcing research activities across various academic disciplines. In so doing, students' works will be visible freely, and can be used for revision tools too.
Albeit these positive responses about Twitter and using it in teaching and learning, some may have reservations about Twitter. In a study conducted by Stollak, Vandenberg, Burklund and Weiss [18], it was found that students who 'appear' active in social media including Twitter may not be able to perform well in their grades. Although the sample used in the study was relatively small, this should be an indicator on how the lecturers plan to use Twitter in their teaching. This study is further supported by findings of Iorliam and Ode [19]. They suggested that the time spent on social media, the frequency of visit and the total number of online friends have a statistically significant relationship with students' academic performance. Notwithstanding this, in another study, it was found that the intensity of using Twitter does not play a significant role in the creation and maintenance of social capital [20]. All in all, what is missing in this debate is the need to educate the students on taking responsibility when using the social media and to use the media more for their learning process.

Some scholars may question whether the revision done using Twitter is promoting deep learning or just surface learning. In deep learning approach, meaningful engagement produces active learning processes that allow students to look at ideas and links of each idea [21]. The researcher argues that due to limited number of words allowed for each tweet, students need to elaborate and link disjointed ideas to make sense of the tweets. Although surface learning could also happen because students may just use tweets to cope with immediate tasks, including answering tests through routine memorisation, the researcher opines that this is normally an initial reaction for first time users of a new strategy to learning. Nonetheless, this paper is unable to analyse further this issue of deep learning versus surface learning whilst using Twitter as a revision tool. Suffice to note at this point that this area is critical and will be the next direction of research in the near future; and suffice to emphasise too that students had shown indications of their ability to link ideas summarised using tweets with appropriate examples (refer to the findings from the survey in later sections).

\section{The Assumptions and Research Questions}

This study does not have a working hypothesis since it is just a preliminary study that looks at how Twitter can be used as an effective revision tool. Therefore, an assumption is made and following that, three research questions are developed. The assumption of this paper is that students perform better in their tests after using Twitter as a revision tool. Following this assumption, three research questions are listed below,

1. How do the tweets assist students to learn?

2. Does Twitter help students to learn effectively?

3. How do students respond to tweets as revision notes?

The research questions will be answered using two tests that had been administered. The results of both tests are compared to examine whether students had benefitted from using Twitter as a revision tool. Screenshots from Twitter are also used to support the analysis and discussion about using Twitter. These screenshots illustrate the tweets, or short notes and retweets. Complementing these, a survey was conducted in order to gauge students' opinions about Twitter as a revision tool. 
Before analysing further, it is pertinent to outline the sections of this paper. There are four sections including this introduction which discusses the background of the study, its significance, selected literature and its assumption together with the research questions. The second section details the methodology of this paper. The third section presents the results from students' tests, screenshots of tweets and also the survey. The last section closes the paper with an in-depth discussion of the findings.

\section{Methodology}

The methodology adopted for this study is a case study approach where class observations were employed together with the tweets posted (these tweets are considered the short notes for revision) and retweets by the students. The results of two tests administered were also used to support the arguments in this paper. Further, a survey was later conducted to explore students' opinions on the use of Twitter as a revision tool. As an action research, this study focuses on trying to investigate whether Twitter can be an effective revision tool.

\section{A. Participants Characteristics}

The number of students used in this research is small; only 32 students who enrolled in the researcher's group for Culture and Development for Semester 1, Academic Session 2014/2015. There were three male students and 29 female students. In terms of categories of students, there were only two military cadets and both of them were female students. These students were in the first semester of their first academic year at the NDUM.

\section{B. Sampling Procedures and Research Design}

The reason for the small number of samples is because there was only one class for the course, and the researcher was the only instructor teaching this course for that semester. The face-to-face sessions were four hours weekly (two hours per session). The semester ran for 14 weeks, and thus students had 56 hours of face-to-face sessions with the researcher. The researcher employed flipped classroom concept, and thus the face-to-face sessions were dedicated to discussions and debates over critical concepts in the course. According to Tucker [22], flipped classroom requires educators to put their teaching videos, lecture notes or reading materials online, and students will have to access these before coming to classes. This gives students more opportunities to talk about the materials that they have accessed, and as such more active and interactive dialogues will happen in the classroom.

Subsequently, the students of the course then were expected to read/watch/listen to the online lectures through the learning management system (LMS) or an e-learning portal before coming to the classes. What traditionally was practised is that students were given lectures during faceto-face sessions. Now, students do their 'homework' with the help of the researcher during face-to-face sessions. In fact, it was observed that back channelling through Twitter (back channel is a digital conversation that happens concurrently with face-to-face activities [23]) happened when students tweeted during the face-to-face discussion.

The students were given Test 1 (administered in Week 6) and Test 2 (administered in Week 12) in order to investigate any improvements in their understanding of critical concepts taught in the course. This intervention using Twitter happened accidently when the researcher realises that students had difficulties in understanding and ultimately using the critical concepts appropriately in Test 1. Although there are various factors that lead to students' difficulties, including the fact that they were only in the first semester of the first year at the Defence University, and the course just started for 6 weeks before the administration of Test 1 , the researcher argues that immediate actions must be taken in order to help students focus and understand critical concepts used and tested in the course. Whilst exploring various strategies, the researcher finally chooses Twitter because of three reasons. First, Twitter is a micro blogging that is omnipresent. This suggests that it can be accessed anytime anywhere. Second, Twitter has functions that allow students to also share the tweets/notes such as retweet function and favourite a tweet function. Students can redirect the revision notes to others and as such keep reading the same notes. Third, because Twitter permits users to update only 140 characters per tweet, the researcher must tweet precise and concise key points. This helps students to focus on the definition and then to discuss the examples on Twitter itself or during face-to-face sessions.

Because there was only one class that offered this course, Culture and Development, there was no control group for this study. If the researcher was to divide the class into two groups, and one group became the control group and the other, the experiment group, it is argued that this might have affected the grades of the students should Twitter be found an effective revision tool. Additionally, there is also the issue of ethical practices if one group became the control group. It would not be fair to the members of the group if Twitter helped in the revision process. Therefore, the researcher opines that the absent of a control group for this study is apt.

In order to validate the findings from the tests and also the screenshots, a survey was conducted to gauge students' opinions on the use of Twitter as a revision tool. The series of questions in the survey came from various questionnaires used by other scholars in their attempt to investigate Web 2.0 tools and micro bloggings. There were three sections in the survey, including the demographic information, issues on using Twitter and the comment section. For the second section, there were 12 items asked to all respondents. Further, a 5-point Likert scale was used for the second section: 1 - Strongly Disagree; 2 - Disagree; 3 - Not Sure; 4 - Agree; and 5 Strongly Agree.

The analysis of data for Tests 1 and 2 was computed using the Statistical Package for Social Sciences (SPSS) Version 18. A paired samples t-test is then used to compare the scores of these tests. The test is able to provide some evidences on any improvements in the students' results when they used Twitter as a revision tool. Further, screenshots of the tweets were also used to support the analysis and discussion. The results from the survey too were analysed using the SPSS for descriptive statistics.

\section{RESUlTS}

Students' scores for Tests 1 and 2 are tabulated in Table 1. All students scored better in Test 2 ; inconclusively it can be summarised that Twitter, amongst other tools and learning approaches, had helped them to revise effectively. On the other hand, it can also be argued that the critical concepts tested in Test 2 were easier or students had had more time to do revision before Test 2 . Nonetheless, the 
researcher would like to emphasise that lessons and topics tested in Test 2 were harder than Test 1 because as the course progressed, more difficult concepts were introduced.

The Shapiro-Wilk $(W) .932(\mathrm{p}>.05)$ for Test 1 and .959 ( $>$.05) for Test 2 suggest that the data are normally distributed (see Table II). This means that the validity of the variables is checked. In addition, Table III presents the paired samples t-test performed on Tests 1 and 2 scores of the students. The test is significant $(\mathrm{t}(31)=-10.508$, $\mathrm{p}<.05)$, thus it shows that Twitter used as a revision tool had successfully assisted students to score better in the second test. Further, the mean score of Test 2 (3.6563) is higher than before Twitter was used (2.0859).

What can be discerned from the data is twofold. Firstly, the students had benefitted from the use of Twitter as a revision tool, although the increase of marks in Test 2 can be contributed to other methods of doing revision. Secondly, the students were given alternative ways to do their revision, and they chose which one better suits them. Twitter is seen as a mobile and accessible revision tool because students carry with them their mobile phones and thus, revision can be done anytime, anywhere.

Further, students were also asked to answer a set of questionnaires on the use of Twitter for revision purposes. The results of the survey are illustrated in Table IV.

Table IV demonstrates that the respondents were able to use Twitter effectively as a revision tool. Based on the survey, it is argued that the majority of the respondents chose between likert scales 4 and 5, which were Agree and Strongly Agree to some items asked in the second section of the survey. The highest mean is on the existence of interesting classroom learning when Twitter was used (4.47), followed by interactivity of classroom lessons when Twitter was used (4.37). The respondents were also confident that they were able to do revision and had effective revision with the use of Twitter; the means are 4.30 and 4.37 respectively. What can be initially concluded is that the tweets sent and shared by the researcher and students benefitted students themselves, and thus Twitter had become one of the effective revision tools for the students.

The screenshots (see Figure 2) illustrate that students used the tweets for revision purposes on critical concepts actively. For every tweet sent by the researcher, who happened to be teaching the course, there would be students who retweeted the tweets and who favourited the tweets. This suggests that the students would have taken the time to read the tweets (this is why it is important to have precise and concise notes/tweets), and then to retweet them to show the importance of the tweets or to show that they had read and would like to share them. The next section will discuss the findings of this paper further by answering the research questions and re-evaluating the assumption posed earlier.

\section{Results}

This section will be based on the assumption made earlier together with the research questions. The research questions will be answered first, followed by justifying the assumption whether it can be accepted or denied.
TABLE I.

THE SCORES OF TESTS 1 AND 2

\begin{tabular}{|c|c|c|c|c|c|}
\hline Students & Test 1 & Test 2 & Students & Test 1 & Test 2 \\
\hline $\begin{array}{l}\text { Student } 1- \\
\text { Female }\end{array}$ & 1 & 4.25 & $\begin{array}{l}\text { Student } 17- \\
\text { Female }\end{array}$ & 2.5 & 4.5 \\
\hline $\begin{array}{l}\text { Student } 2 \text { - } \\
\text { Female }\end{array}$ & 0.75 & 4.25 & $\begin{array}{l}\text { Student } 18- \\
\text { Male }\end{array}$ & 1.25 & 3 \\
\hline $\begin{array}{l}\text { Student } 3- \\
\text { Female }\end{array}$ & 1.25 & 3.75 & $\begin{array}{l}\text { Student } 19- \\
\text { Female }\end{array}$ & 1.25 & 4.5 \\
\hline $\begin{array}{l}\text { Student } 4- \\
\text { Female }\end{array}$ & 1.5 & 3.25 & $\begin{array}{l}\text { Student } 20- \\
\text { Female }\end{array}$ & 1.5 & 3.5 \\
\hline $\begin{array}{l}\text { Student } 5 \text { - } \\
\text { Female }\end{array}$ & 3 & 4.75 & $\begin{array}{l}\text { Student } 21 \text { - } \\
\text { Female }\end{array}$ & 2.75 & 4.5 \\
\hline $\begin{array}{l}\text { Student } 6- \\
\text { Female }\end{array}$ & 2 & 3.75 & $\begin{array}{l}\text { Student } 22- \\
\text { Female }\end{array}$ & 2.5 & 3.25 \\
\hline $\begin{array}{l}\text { Student } 7 \text { - } \\
\text { Female }\end{array}$ & 2.5 & 3 & $\begin{array}{l}\text { Student } 23 \text { - } \\
\text { Female }\end{array}$ & 1.5 & 2.75 \\
\hline $\begin{array}{l}\text { Student } 8 \text { - } \\
\text { Male }\end{array}$ & 3 & 3.5 & $\begin{array}{l}\text { Student } 24 \text { - } \\
\text { Female }\end{array}$ & 2.75 & 4 \\
\hline $\begin{array}{l}\text { Student } 9 \text { - } \\
\text { Female }\end{array}$ & 2.25 & 3.5 & $\begin{array}{l}\text { Student } 25 \text { - } \\
\text { Female }\end{array}$ & 1.75 & 3 \\
\hline $\begin{array}{l}\text { Student } 10- \\
\text { Male }\end{array}$ & 1.5 & 2.25 & $\begin{array}{l}\text { Student } 26- \\
\text { Female }\end{array}$ & 2 & 2.5 \\
\hline $\begin{array}{l}\text { Student } 11- \\
\text { Female }\end{array}$ & 2.75 & 3.25 & $\begin{array}{l}\text { Student } 27- \\
\text { Female }\end{array}$ & 2.5 & 3 \\
\hline $\begin{array}{l}\text { Student } 12- \\
\text { Female }\end{array}$ & 1.75 & 4 & $\begin{array}{l}\text { Student } 28- \\
\text { Female }\end{array}$ & 2 & 4.5 \\
\hline $\begin{array}{l}\text { Student } 13 \text { - } \\
\text { Female }\end{array}$ & 2.75 & 4.25 & $\begin{array}{l}\text { Student } 29- \\
\text { Female }\end{array}$ & 1.75 & 3.75 \\
\hline $\begin{array}{l}\text { Student } 14- \\
\text { Female }\end{array}$ & 2.75 & 3.25 & $\begin{array}{l}\text { Student } 30- \\
\text { Female }\end{array}$ & 1.5 & 3.25 \\
\hline $\begin{array}{l}\text { Student } 15- \\
\text { Female }\end{array}$ & 3 & 4.75 & $\begin{array}{l}\text { Student } 31- \\
\text { Female }\end{array}$ & 2.5 & 3.25 \\
\hline $\begin{array}{l}\text { Student } 16- \\
\text { Female }\end{array}$ & 2.75 & 3.75 & $\begin{array}{l}\text { Student } 32- \\
\text { Female }\end{array}$ & 2.25 & 4.25 \\
\hline
\end{tabular}

TABLE II.

TESTS OF NORMALITY

\begin{tabular}{lcccccc}
\hline & \multicolumn{3}{c}{ Kolmogorov-Smirnova } & \multicolumn{3}{c}{ Shapiro-Wilk } \\
\cline { 2 - 7 } & Statistic & $\boldsymbol{d} \boldsymbol{f}$ & Sig. & Statistic & $\boldsymbol{d f}$ & Sig. \\
\hline Test 1 & .175 & 32 & .014 & .932 & 32 & .043 \\
Test 2 & .135 & 32 & .148 & .959 & 32 & .261 \\
Difference & .118 & 32 & $.200^{*}$ & .922 & 32 & .024
\end{tabular}

a. Lilliefors Significance Correction

$*$. This is a lower bound of the true significance

TABLE III.

THE DifFERENCES BETWEEN TESTS 1 AND 2 RESUlts

\begin{tabular}{|c|c|c|c|c|c|c|}
\hline Test & $\mathbf{N}$ & Mean & $\begin{array}{l}\text { Std. Devia- } \\
\text { tion }\end{array}$ & df & $\mathbf{t}$ & p* \\
\hline Test 1 & 32 & 2.0859 & 0.65257 & \multirow{2}{*}{31} & \multirow{2}{*}{-10.508} & \multirow{2}{*}{.000} \\
\hline Test 2 & 32 & 3.6563 & 0.66826 & & & \\
\hline
\end{tabular}

TABLE IV.

THE EFFECTIVENESS OF TWITTER AS A REVISION TOOL

\begin{tabular}{lcc}
\hline \multicolumn{1}{c}{ Items } & Mean & Std. Deviation \\
\hline Interesting Classroom Learning & 4.47 & .571 \\
Interactive Classroom Learning & 4.37 & .615 \\
Use for Revision & 4.30 & .877 \\
Effective Revision & 4.37 & .669 \\
Better Understanding & 4.30 & .702 \\
Provide Examples Themselves & 4.07 & .691 \\
\hline
\end{tabular}




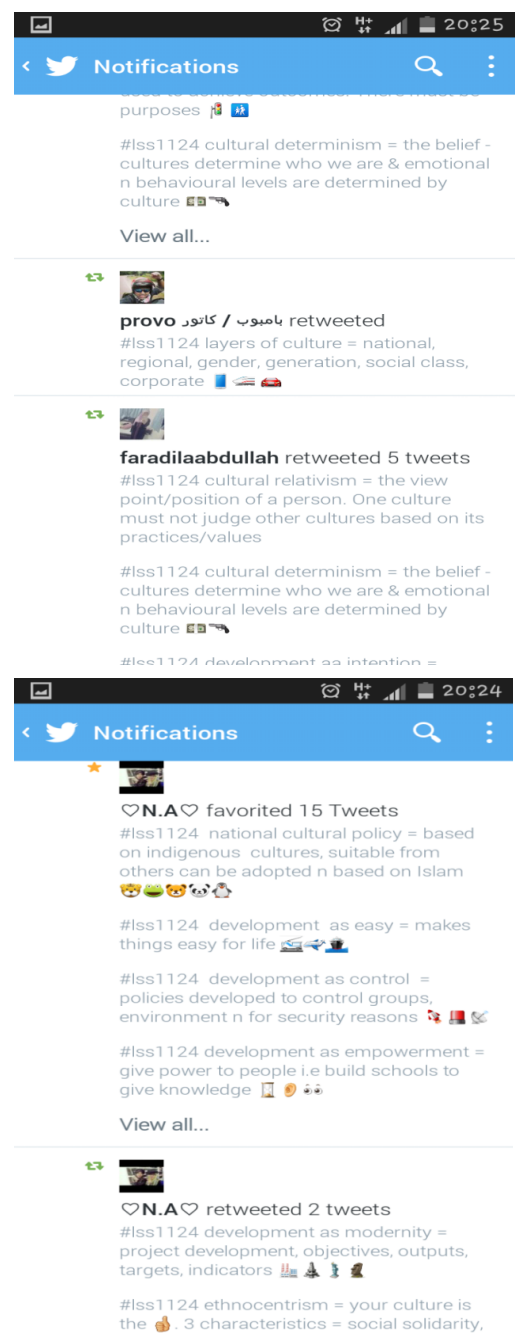

Figure 2. Screenshots of tweets and retweets

\section{A. Research Question $1-$ How do the tweets assist students to learn?}

Based on the literature review, the results of Tests 1 and 2 and the screenshots of tweets, the researcher argues that the tweets helped students to decipher critical concepts easily. There are two explanations for this argument. Firstly, due to the nature of tweets, which only allows a maximum of 140 characters per tweet, the researcher is bound to provide precise and concise tweets or notes. Lengthy explanation, which can be confusing, is not practical for Twitter. Pedagogically, key points allow students to better understand the lessons of the day. Secondly, since the hashtag \#lle1124 was used to mark the tweets on critical concepts, students can easily search the hashtag and they will be directed to all critical concepts within seconds. Further, these tweets remain in Twitter, and thus students can get access to them anytime anywhere.

The respondents believed that the tweets had assisted them to learn, as illustrated in Table V. Although there were respondents who chose Disagree in answering these items in Table $\mathrm{V}$, the majority opted to agree with the items (the means range from 4.37 to 4.47). The classroom learning became interesting and interactive because students were kept busy with tweeting and retweeting critical concepts. Students became active too (back channelling, that is, the students were having digital conversations) because they were not only physically engaged but also digitally occupied with the lessons of the day.

\section{B. Research Question 2-Does Twitter help students to learn effectively?}

Again, this research question can be answered using the results of Tests 1 and 2. All students scored higher in Test 2. Since Test 2 was more difficult than Test 1, where students scored poorly, it can be concluded that Twitter, whether directly or indirectly had assisted students to learn effectively. This is because they could get access to the tweets wherever they were and whilst doing almost anything. 'Effectively' in this research question gauges students' performance before and after notes were tweeted in Twitter. As explained previously, because students were able to access the tweets anytime anywhere, they were able to better use and manage these notes efficiently. Not only could the tweets be used individually by the students, but the students may also revise in groups or in pairs by asking questions through retweeting or meeting face-toface.

Table VI outlines the important items asked on whether students were able to do revision effectively with Twitter. It shows that students were optimistic about their own ability to provide examples for themselves although the tweets were short (only 140 characters). This means that once students understood the critical concepts, they would be able to link all related points to make concrete understanding of the ideas. In addition, although some respondents opted for Strongly Disagree for the item Use for Revision, the mean, 4.30, demonstrates that the majority of the respondents believed in Twitter for assisting them to do revision.

\section{Research Question 3 - How do students respond to tweets as revision notes?}

The last research question can be answered by examining the results of the students in Test 2, Tables 5 and 6 , together with the screenshots in Figures 2 and 3 below. Students positively used the tweets and accepted Twitter as a revision tool. The researcher observes that students became more active during classroom sessions because they had had the tweets to simplify the process of doing

TABLE V.

ITEMS FOR ASSISTING STUDENTS TO LEARN USING TwITTER

\begin{tabular}{lcccc}
\hline & Minimum & Maximum & Mean & $\begin{array}{c}\text { Std. Devia- } \\
\text { tion }\end{array}$ \\
\hline $\begin{array}{l}\text { Interesting Classroom } \\
\text { Learning }\end{array}$ & 3 & 5 & 4.47 & .571 \\
$\begin{array}{l}\text { Interactive Classroom } \\
\text { Learning }\end{array}$ & 3 & 5 & 4.37 & .615 \\
Back channelling & 2 & 5 & 4.37 & .765 \\
\hline
\end{tabular}

TABLE VI.

ITEMS FOR DOING REVISION EFFECTIVELY WITH TWITTER

\begin{tabular}{lcccc}
\hline & Minimum & Maximum & Mean & $\begin{array}{c}\text { Std. } \\
\text { Deviation }\end{array}$ \\
\hline Use for Revision & 1 & 5 & 4.30 & .877 \\
Effective Revision & 3 & 5 & 4.37 & .669 \\
Better Understanding & 3 & 5 & 4.30 & .702 \\
$\begin{array}{l}\text { Provide Examples Them- } \\
\text { selves }\end{array}$ & 3 & 5 & 4.07 & .691 \\
\end{tabular}




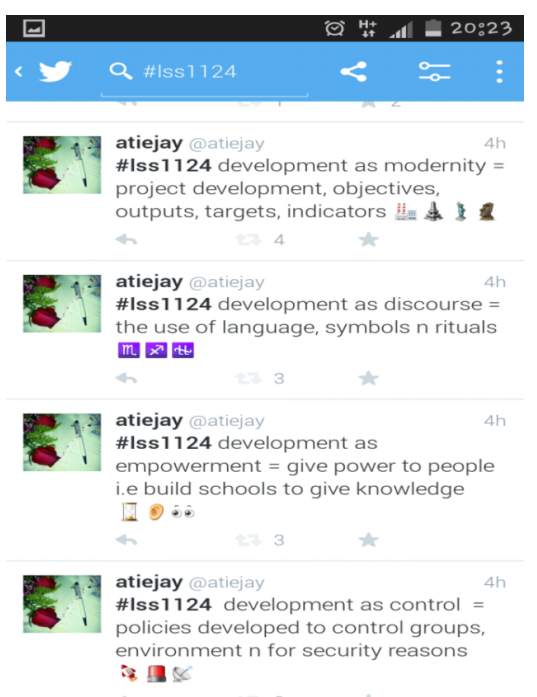

Figure 3. Another screenshot of tweets and retweets

their revision. What surprises the researcher is that the students were able to relate the tweets to relevant examples when needed during classroom learning. This suggests that students had understood the concepts well and that in so doing, they are able to link relevant examples to further explain the concepts.

Based on all the above arguments, the assumption posed earlier could easily be accepted, that students performed better in their tests (Test 2) after using Twitter as a revision tool. Although other factors may have contributed to students' better performance, this paper has added some insights into the existing literature on the advantages of using Twitter for teaching and learning. For this paper, the argument is about how Twitter assists students to do their revision or how Twitter can be used as a revision tool. As the way of learning changes day by day, these Digital Natives must be given learning tools that match their demands and expectations. Perhaps, what was predicted by Dewey [24] is fitting, in that, educators today should not teach the current students with how the educators themselves were taught since this would only rob the students of their future.

Notwithstanding this, the researcher admits to two main limitations. First, there is no inferential statistics done to answer the research questions. This can weaken the whole arguments as a whole. However, the researcher would like to emphasise that this is just the first documentation of the use of Twitter as a revision tool at the Defence University. Hence, as an initial initiative, the methods adopted in this paper were considered sufficient by the researcher. Second, the students who participated in the course should have been interviewed in order to individually gauge their responses about the use of Twitter as a revision tool. The data will support the existing understanding about the use of Twitter as a revision tool. The researcher plans to extend this study in the near future using a more improvised research method as well as analytical tool.

To conclude, as an exploratory and brief research paper, the researcher is convinced that Twitter can be used as an effective revision tool provided that some guidelines are followed accordingly. These include the manner whilst using Twitter and most importantly, how to phrase the tweets or notes. In fact, this must be addressed immediately since there is no model for teaching and learning with
Twitter, especially in higher education [25]. As shown in the findings, students had tremendously increased their scores in Test 2, that is, after Twitter was used to help them in their revision for the test. What is unknown is that whether the tweets were the only element that had helped the students, or whether there were other factors involved. This will also be part of the next research area on using Twitter as a revision tool.

\section{ACKNOWLEDGMENT}

The researcher would like to thank all her students who were in the group for the course. Further, the researcher also would like to thank the University for granting the permission to conduct this action research.

\section{REFERENCES}

[1] M. Schwartz, "Social Media and Web 2.0 in the Classroom Learning and Teaching Office," Retrieved from http://www.ryerson.ca/lt/, 2012.

[2] M. Prensky, Teaching Digital Natives. California: Corwin, 2010.

[3] B. Cornu, "Digital Natives: How Do They Learn? How To Teach Them," Policy Brief, Moscow: UNESCO Institute for Information Technologies in Education, 2011.

[4] A. Mollet, D. Moran and P. Dunleavy, "Using Twitter in University Research, Teaching and Impact Activities," in Impact of Social Sciences: Maximising the Impact of Academic Research. London: LSE Public Policy Group, 2011.

[5] G. Ferenstein, "How Twitter in the Classroom is Boosting Student Engagement," Retrieved from http://mashable.com/2010/03/01/twitter-classroom/, 2010.

[6] J.C. Dunlop and P.R. Lowenthal, "Tweeting the Night Away: Using Twitter to Enhance Social Presence," Journal of Information Systems Education, vol. 20, no. 2, pp. 129-155, 2009.

[7] J. Marr and C.S. DeWaele, "Incorporating Twitter within the Sport Management Classroom: Rules and Uses for Effective Practical Application," Journal of Hospitality, Leisure, Sport and Tourism Education, vol. 17, pp. 1-4, 2015. http://dx.doi.org/10.1016/ j.jhlste.2015.05.001

[8] M.M.M. Abdel Malak, "Web 2.0 Technologies and Building Online Learning Communities: Students' Perspectives," Journal of Asynchronous Learning Network, vol. 19, issue 2, pp. 20-31, 2015.

[9] M.A. Embi, Web 2.0 Tools in Education: A Quick Guide. Bangi: Centre for Academic Advancement, 2011.

[10] J.C. Dunlop and P.R. Lowenthal, "Tweeting the Night Away: Using Twitter to Enhance Social Presence," Journal of Information Systems Education, vol. 20, no. 2, pp. 129-155, 2009.

[11] T. Luo and F. Gao, "Enhancing Classroom Learning Experience by Providing Structures to Microblogging-based Activities," Journal of Information Technology Education: Innovation in Practice, vol. 11, pp. 129-211, 2012.

[12] J.A. McArthur and K. Bostedo-Conway, "Exploring Relationship Between Student-Instructor Interaction on Twitter and Student Perceptions of Teacher Behaviours," International Journal of Teaching and Learning in Higher Education, vol. 24, no. 3, pp. 286-292, 2012.

[13] I. Yakin and H. Tinmaz, "Using Twitter as an Instructional Tool: A Case Study in Higher Education,"Turkish Online Journal of Educational Technology, vol. 12, issue 4, pp. 209-218, 2013.

[14] J.H. Kuznekoff, S. Munz and S. Titsworth, "Mobile Phones in the Classroom: Examining the Effects of Texting, Twitter and Message Content on Student Learning," Communication Education, vol. 64, issue 3, pp. 344-365, 2015. http://dx.doi.org/10.1080/ 03634523.2015 .1038727

[15] M. Sample, "Revised Twitter Adoption Matrix," Retrieved from http://digitalis.nwp.org/sites/default/files/files/9/Revised\%20Twitt er\%20Adoption\%20Matrix.pdf, 2009.

[16] Mollet, D. Moran and P. Dunleavy, "Using Twitter in University Research, Teaching and Impact Activities," in Impact of Social Sciences: Maximising the Impact of Academic Research. London: LSE Public Policy Group, 2011. 
[17] A. Mollet, D. Moran and P. Dunleavy, "Using Twitter in University Research, Teaching and Impact Activities," in Impact of Social Sciences: Maximising the Impact of Academic Research. London: LSE Public Policy Group, 2011.

[18] M.J Stollak, A. Vandenberg, A. Burklund and S. Weiss, "Getting Social: The Impact of Social Networking Usage on Grades Amongst College Students," Proceeding of ASBBS, vol. 18, no. 1, pp. 858-865, 2011.

[19] A. Iorliam and E. Ode, "The Impact of Social Network Usage on University Students' Academic Performance: A Case Study of Benue State University Makurdi, Nigeria," International Journal on Computer Science and Engineering, vol. 6, no. 7, pp. 275-279, 2014.

[20] C. Petersen and K.A. Johnston, "The Impact of Social Media Usage on the Cognitive Social Capital of University Students," Informing Science, vol. 18, issue 1, pp. 1-31, 2015.

[21] N. Entwistle, "Promoting Deep Learning Through Teaching and Assessment: Conceptual Frameworks and Educational Contexts," Conference Proceedings TLRP, Leicester, 2000.
[22] B. Tucker, "The Flipped Classroom: Online Instruction at Home Frees Class Time for Learning," Education Next, Winter, pp-82$83,2012$.

[23] B. Holland, "The Backchannel: Giving Every Student A Voice in the Blended Mobile Classroom," Retrieved from http://www.edutopia.org/blog/backchannel-student-voice-blendedclassroom-beth-holland, 2014.

[24] J. Dewey, School of Tomorrow, New York: Dutton, 1915.

[25] C. Greenhow, B. Robelia and E. Hughes, "Web 20. And Classroom Research: What Path Should We Take Now," Educational Researcher, vol. 38, no. 4, pp. 246-259, 2009. http://dx.doi.org/10.3102/0013189X09336671

\section{AUTHORS}

J. Juhary is with the National Defence University of Malaysia, Sungai Besi Camp, 57000 Kuala Lumpur, Malaysia (e-mail: atiejay@gmail.com).

Manuscript received 09 October 2015. Published as resubmitted by the author 13 March 2016. 